\title{
ANAEROBIC TECHNOLOGY FOR TREATMENTOF CONCENTRATED WASTEWATER FROM ESTONIAN FOOD INDUSTRIES
}

\author{
H.MÖLDER \\ V.BLONSKAYA \\ Tallinn Technical University, Estonia
}

\section{ABSTRACT}

Anaerobic wastewater treatment technologies are used throughout the world for effective treatment of a wide variety of industrial wastewater, in particular for the wastewater from the food industry. This type of wastewater is rich in easily biodegradable carbohydrates and has a relatively low content in suspended solids. As an example, the anaerobic bio-degradation of organic matter in wastewater ( cheese whey ) was studied on a laboratory - scale Upflow Anaerobic Sludge Blanket Reactor (UASB). This wastewater was found characterized by high COD concentration, from 58.000 to $72.000 \mathrm{mg} / \mathrm{L}$. The digester efficiency during the treatment process of cheese wastewater at various organic loading rates $(0.5-$ $16 \mathrm{~kg} \mathrm{COD} / \mathrm{m}^{3}$. day ) was studied and its performance was assessed by monitoring the $\mathrm{pH}$ value ( $6.8-7.3$ ) and biogas production ( up to $24 \mathrm{~L} /$ day ). The investigation has demonstrated that the process of anaerobic degradation was sufficiently effiective for COD removal.

\section{KEYWORDS}

Food industry; cheese whey; biodegradable organic; anaerobic treatment; UASB-reactor.

\section{INTRODUCTION}

The food industry is one of the major contributors of wastewater pollution. Estonia has 70 small enterprises of the food industry, some of them have very small flow rates ( some $\mathrm{m}^{3}$ per day ). Today (1999) some of enterprises are pumping their wastewater to the wastewater treatment plants of towns and others have local treatment plants. In many cases the local treatment plants are rather old and work inefficiently. The quality of wastewater varies according to the branch of industry and mill type, but all wastewater from food industries 
contains an organic matter which is easily biodegradable. Most of effluents are also rich in phosphorus and nitrogen, mostly originating from raw materials or products, but some also from washing. As seen from Table 1, pollutant concentrations in municipal wastewater discharge are substantially higher of the limiting permissible concentrations, especially $\mathrm{BOD}_{7}$ and phosphorus. The average wastewater concentrations are: $\mathrm{BOD}_{7}-1177 \mathrm{mg} / \mathrm{L}, \mathrm{SS}-261$ $\mathrm{mg} / \mathrm{L}$, phosphorus $-19,1 \mathrm{mg} / \mathrm{L}$, nitrogen $-57,9 \mathrm{mg} / \mathrm{L}$ and ratio BOD : $\mathrm{N}: \mathrm{P}$ is $100: 4,9: 1,6$.

TABLE 1 The characteristics of the food industry effluent

\begin{tabular}{|c|c|c|c|c|c|c|c|}
\hline \multirow{2}{*}{ Industry } & \multirow{2}{*}{$\begin{array}{l}\text { Number of } \\
\text { enterprises }\end{array}$} & \multirow{2}{*}{$\begin{array}{l}\text { Effluent } \\
\mathrm{Q}, \\
\mathrm{m}^{3} / \text { day }\end{array}$} & \multicolumn{5}{|c|}{ Average concentration of pollutants } \\
\hline & & & $\mathrm{pH}$ & $\begin{array}{l}\mathrm{BOD} \\
\mathrm{mg} / \mathrm{L}\end{array}$ & $\begin{array}{l}\mathrm{SS} \\
\mathrm{mg} / \mathrm{L}\end{array}$ & $\begin{array}{l}\mathrm{P}_{\text {tot }} \\
\mathrm{mg} / \mathrm{L}\end{array}$ & $\begin{array}{l}\mathrm{N}_{\mathrm{tot}} \\
\mathrm{mg} / \mathrm{L}\end{array}$ \\
\hline Slaughterhouses & 2 & $15-500$ & 6.0 & 1100 & 144 & 13 & 85 \\
\hline Fish & 20 & $15-745$ & 7.1 & 953 & 425 & 30 & 93 \\
\hline Dairies & 16 & $5-3800$ & 7.1 & 830 & 507 & 15 & 90 \\
\hline Cheese & 6 & $61-660$ & - & 1002 & 253 & 23 & 63 \\
\hline Meat & 7 & $16-4400$ & 7.6 & 575 & 375 & 16 & 78 \\
\hline Potatoe chips & 1 & 334 & - & 1557 & - & 35 & 35 \\
\hline Yeast & 1 & 587 & - & 6000 & 100 & 17 & 100 \\
\hline Bread, muffin & 9 & $15-70$ & 7.3 & 901 & 455 & 8.5 & 2.9 \\
\hline Starch & 2 & $16-300$ & - & 718 & 150 & 10 & 50 \\
\hline Alcohol: & 2 & 50 & 8.9 & 269 & 104 & 14 & 41 \\
\hline beer & 6 & $35-500$ & 7.3 & 675 & 288 & 9.6 & 55 \\
\hline drinks, wine & 4 & $60-353$ & 9.3 & 1113 & 229 & 44 & 56 \\
\hline spirits & 3 & $100-590$ & 6.95 & 615 & 101 & 13 & 4 \\
\hline \multicolumn{3}{|c|}{$\begin{array}{l}\text { Limiting admissible concentra- } \\
\text { tion if discharged into public sewerage }\end{array}$} & $6.5-8.5$ & 375 & 500 & 10.5 & 100 \\
\hline
\end{tabular}

The temperature of wastewater is higher than that of municipal waters. Wastewater from the food industry contains proteins, fats, lactose, etc. Full utilization of all wastes on spot and their reuse at the manufactures are naturally the best method for most food industry enterprises. But these technologies are rather complicated and expensive for use in small enterprises. A biological wastes treatment may be a good alternative in such cases. In Estonia, in the majority of cases aerobic processes are used for municipal and industrial wastewater treatment. However, the wastes of food industries are categorized as medium strength organic wastewater, requiring an intensive amount of energy for aeration. Besides, a large amount of waste sludge is generated from these aerobic processes. On the other hand, anaerobic treatment technologies are used throughout the world for the effiective treatment of a wide variety of industrial wastewater. The main advantages of the anaerobic treatment are ( Malina, 1992): low production of biological sludge, high treatment efficiency, low capital cost, no oxygen requirement, methane production (potential source of fuel), low nutrient requirement, low operating cost.

The comparison of an anaerobic and aerobic processes is shown in Figure 1. 

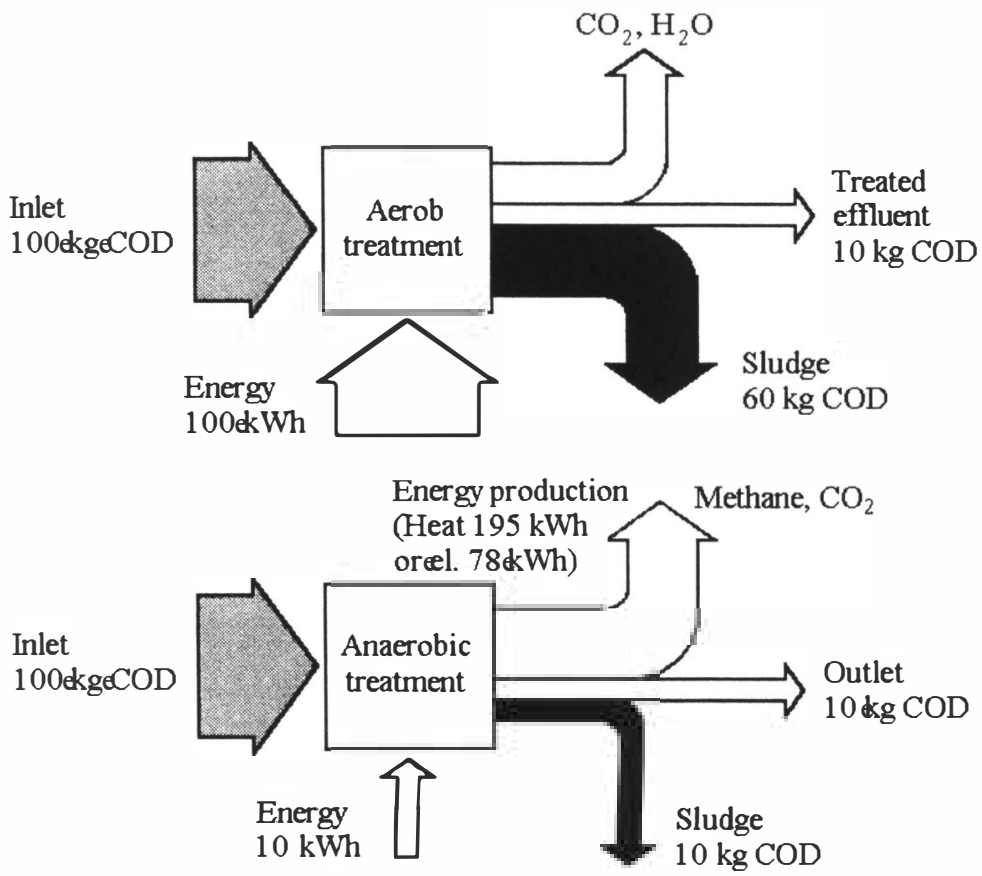

Fig. 1. The comparison of an anaerobic and aerobic processes

Figure 2 summarizes the many anaerobic designs that are currently in use for full-scale treatment applications ( Sutton, 1990 ).

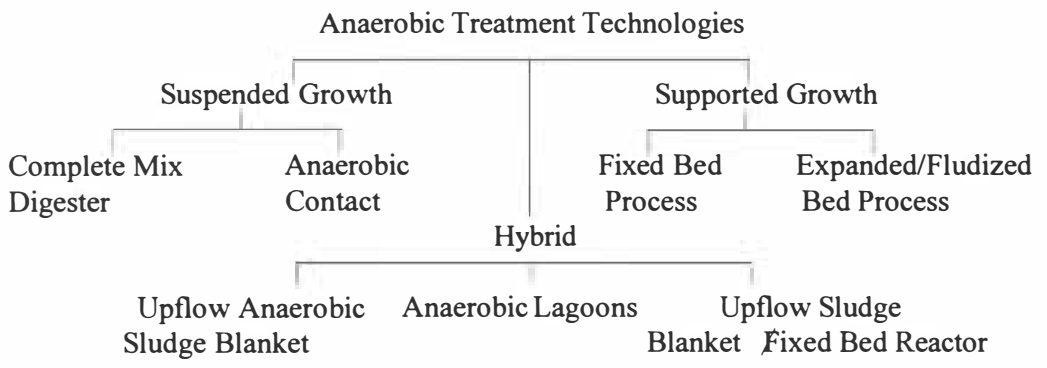

Fig. 2. Commonly used full-scale anaerobic treatment processes.

Table 2 summarizes the main parameters of the anaerobic treatment processes in the wastewater of the food industry (Hanging,1996; Kalyuzhnyi,1991, 1997; Lettinga et. al. 1997; Seyfried, 1997). 
TABLE 2 Main parameters of the anaerobic treatment processes in the wastewater of the food industry

\begin{tabular}{|c|c|c|c|c|c|}
\hline Industry & $\begin{array}{l}\text { Type of the } \\
\text { reactor }\end{array}$ & $\begin{array}{l}\text { Wastewater } \\
\text { concentration, mg } \\
\mathrm{COD} / \mathrm{L}\end{array}$ & $\begin{array}{l}\text { Load, } \\
\frac{\mathrm{kg} \mathrm{COD}}{\mathrm{m}^{3} \cdot \text { day }}\end{array}$ & $\begin{array}{l}\text { HRT, } \\
\text { Day }\end{array}$ & $\begin{array}{l}\text { Effect } \\
\text { of treat- } \\
\text { ment, \% }\end{array}$ \\
\hline Beer & UASB & $1300-460045000$ & $1.4-14.9$ & $5.6-9$ & $75-80$ \\
\hline \multirow[t]{3}{*}{ Starch } & $\mathrm{H}$ & 4500 & 4 & 228 & 97 \\
\hline & $\mathrm{AF}$ & 10000 & 10.8 & 10 & 80 \\
\hline & UASB & 8000 & 15 & 18 & $90-95$ \\
\hline \multirow[t]{2}{*}{ Potatoes } & $\mathrm{AF}$ & 7500 & 8 & $24-26$ & $80-93$ \\
\hline & $\mathrm{H}$ & 28000 & 11.6 & 16.3 & 70 \\
\hline \multirow[t]{3}{*}{ Dairies } & FB & 1600 & 7 & 24 & 80 \\
\hline & $\mathrm{H}$ & $3000-33000$ & 2 & 20 & 70 \\
\hline & UASB & 3200 & 12 & 65 & 85 \\
\hline \multirow[t]{4}{*}{ Cheese } & FB & $40000-70000$ & 22 & 2.4 & 70 \\
\hline & $\mathrm{AF}$ & 3600 & $8-15.6$ & $96-120$ & $82-85$ \\
\hline & $\mathrm{H}$ & $3000-4500$ & 216 & 85 & 90 \\
\hline & UASB & & $3.5-15$ & $6-8.2$ & $92-95$ \\
\hline
\end{tabular}

UASB - Upflow Anaerobic Sludge Blanket

$$
\begin{array}{ll}
\mathrm{H} & - \text { Hybrid } \\
\text { AF } & - \text { Anaerobic Filter } \\
\text { FB } & - \text { Fixed Bed Processes }
\end{array}
$$

The best step is the local wastewater treated with the UASB process. The UASB process is the most economical system and may be used for various types of wastewater from the food industry. Advantages of this type of reactor are: to provide a polishing effect to the effluent, start-up time of reactor is short, well-established anaerobic treatment systems, to prevent the washout of viable bacterial matter. This type of reactor is characterized by the highly flocculated, well settling, compact methano-genic sludge granular, resulting in a very high biomass content (Gavala, 1998).

\section{MATERIALS and METHODS}

Milk processing is the largest sector of the food industry in Estonia, and therefore it was necessary to search an environmental friendly solution for its wastes. Anaerobic treatment of highly concentrated waste of the cheese industry was studied at the laboratory pilot-plant. The experi-mental pilot plant consisted of five-litre volume packed bed reactors, a sedimentation tank, a feed tank, and a gas collection tank (Figure 3). Temperature was maintained by an electric heating mat wrapped around the external wall of the reactor. The $\mathrm{COD}, \mathrm{N}_{\text {tot }}, \mathrm{P}_{\text {tot }}$, dry matter, alkalinity, volatile fatty acids of wastewater and effluent were measured twice a week. Flow rates, biogas

production rate and effluent $\mathrm{pH}$ were measured daily. 


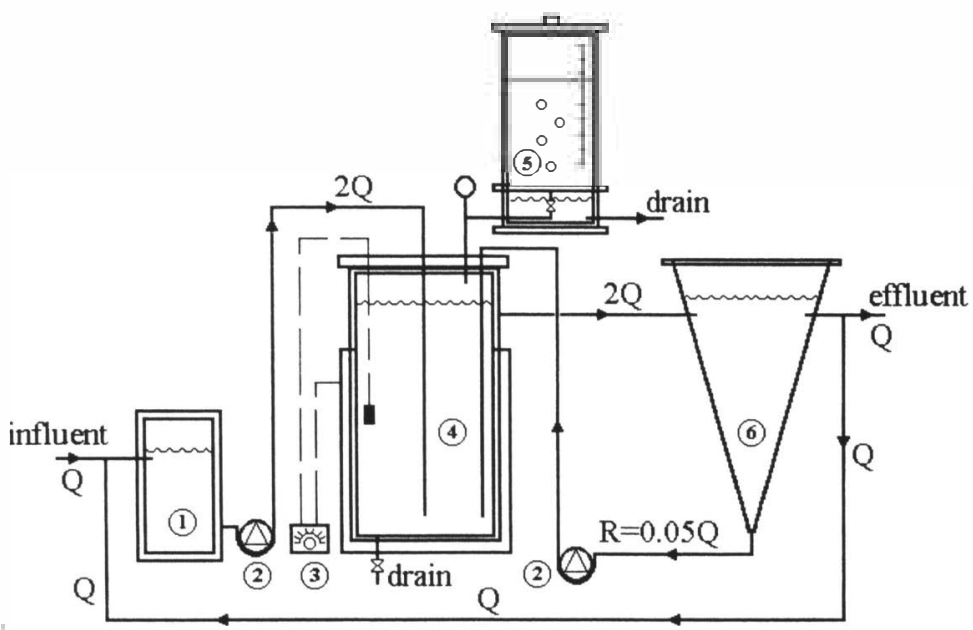

Fig. 3. Scheme of an anaerobic digester

$$
\begin{array}{ll}
1 \text { - feed tank } & 4 \text { - anaerobic reactor (volume }-4.8 \mathrm{~L} \text { ) } \\
2 \text { - pump } & 5 \text {-gas collection tank } \\
3 \text { - temperature control } & 6 \text { - sedimentation tan }
\end{array}
$$

The chemical characteristics of the studied wastewater whey from the cheese industry was : COD $58.800-73.100 \mathrm{mg} / \mathrm{L}$; dry matter $56.000-72.000 \mathrm{mg} / \mathrm{L} ; \mathrm{pH} 3.8-6.3 ; \mathrm{N}_{\text {tot }} 760-1.420$ $\mathrm{mg} / \mathrm{L} ; \mathrm{P}$ tot $368-720 \mathrm{mg} / \mathrm{L}$

\section{RESULTS and DISCUSSION}

The efficiency of the anaerobic treatment process is mainly determined by a proper start-up of the reactor. UASB reactor started up with granular sludge ( $20 \%$ of the volume of the reactor ) from one of the full-scale plant working at the sugar industry. The initial sludge loading rate was well below approximately $50 \%$ of its maximum potential during the first week. A slowly rising load ( $5 \%$ a week ) did not create any problems. It should be noted that the HRT applied was usually shorter than five days, considered ( Yan et. al., 1993 ) as minimal admissible HRT to achieve stable operation of anaerobic reactors treating raw cheese whey. Main operating conditions for the UASB reactor were :

$\begin{array}{ll}\text { Days of experiment } & 1.03 .98 \cdot-2.07 .98 . \\ & 1.09 .98 \cdot-3.03 .99 . \\ \text { Temperature } & 35-37^{\circ} \mathrm{C} \\ \text { Sludge load } & 0.5-16 \mathrm{~kg} \mathrm{COD} / \mathrm{m}^{3} \cdot \text { day } \\ \text { HRT } & 2.5-12 \text { days } \\ \text { Gas production } & 0-24 \mathrm{~L} / \text { day } \\ & 0-0.814 \mathrm{~L} / \mathrm{g} \mathrm{COD} \text { removed } \\ \text { Reduction of COD } & 53-98 \%\end{array}$


The effluent $\mathrm{pH}$ was kept at $6.8-7.3$, due to the chemical buffer in the wastewater. Figure 4 shows the change of main parameters during the experiments. Biogas production and composition were measured throughout the experiment. The gas produced was composed of $78 \%$ methane, $20 \%$ carbon dioxide and $2 \%$ nitrogen, which was comparable to the figures reported in literature. The gas production rate increased line- arly with an increased COD load. Figure 5 shows that maximum digester COD removal efficiency $98 \%$ was achieved before the load $3.5 \mathrm{~kg} \mathrm{COD} / \mathrm{m}^{3}$. day. When increasing the influent $\mathrm{COD}$ concentration to $32.948 \mathrm{~g} / \mathrm{L}$ (load $7.44 \mathrm{~kg} \mathrm{COD} / \mathrm{m}^{3}$ - day), the COD removal efficiency was reduced to $70 \%$ with a mean COD effluent concentration $15.60 \mathrm{~g} / \mathrm{L}$. Figure 6 shows the relationship between the organic load, biogas production and HRT.

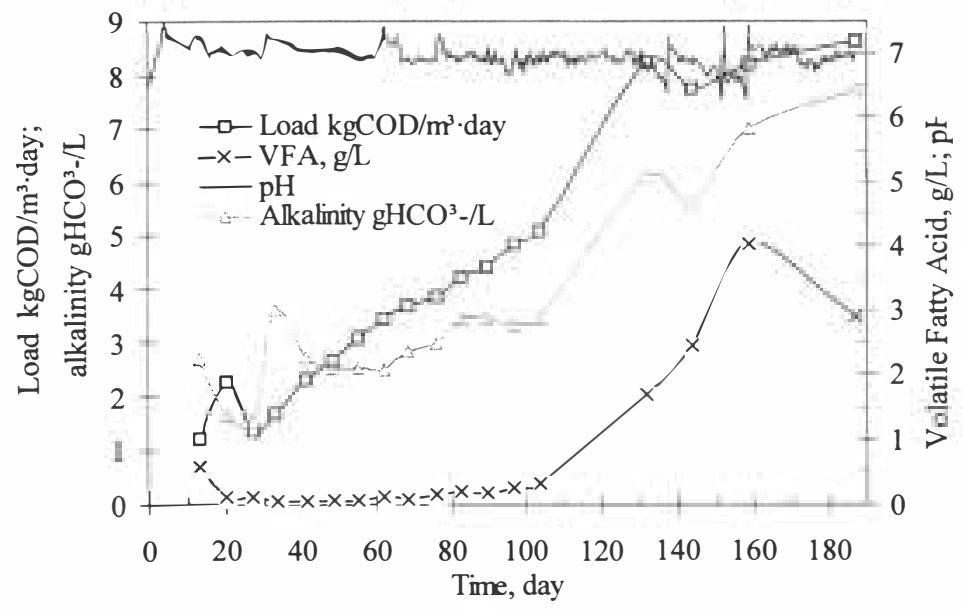

Fig. 4. Organic load, pH, VFA, and alkalinity changes time 


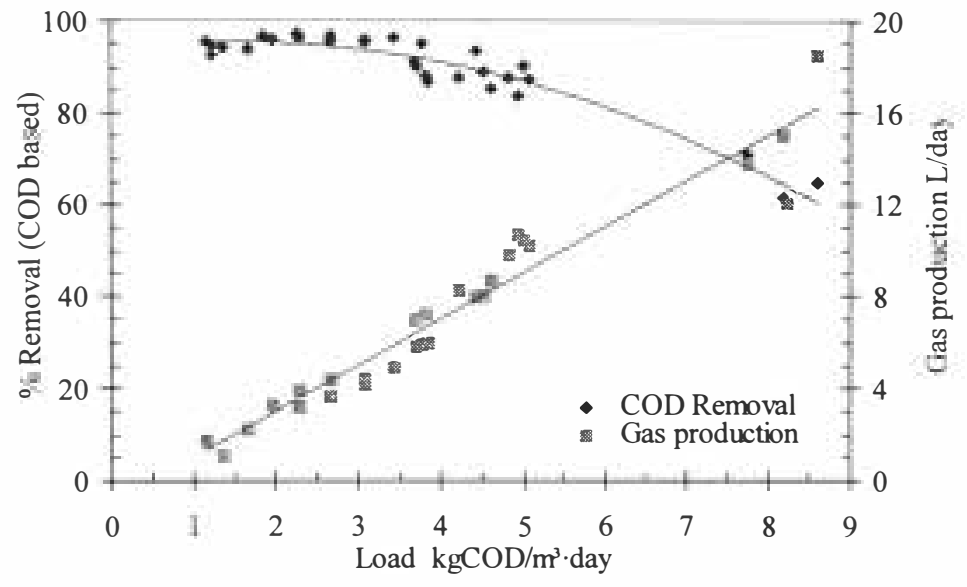

Fig. 5. Relationship between COD removal efficiency, gas production, and organic load

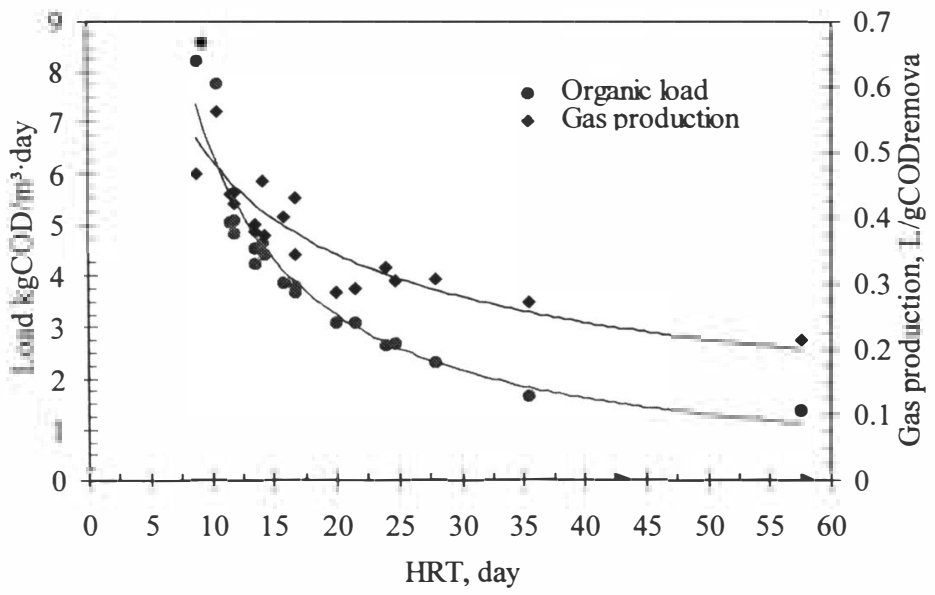

Fig. 6. Relationship between organic load, gas production and HRT

The results of the experiment are summarized in Table 3 . 
TABLE 3 Wastewater quality after treatment

\begin{tabular}{|l|c|}
\hline Parameters & Concentration $\mathrm{mg} / \mathrm{L}$ \\
\hline $\mathrm{COD}$ & 2767 \\
Dry matter & 6.33 \\
Alkalinity & 2770 \\
Volatile acids & 943 \\
$\mathrm{~N}_{\text {tot }}$ & 438 \\
$\mathrm{P}_{\text {tot }}$ & 69 \\
\hline
\end{tabular}

The maximum COD removal was achieved with a relationship between fatty acid and alkalinity of 0.2 , such as for a well-balanced system. When increasing this relationship from 0.6 to 1.0 , the COD removal efficiency was reduced from 80 to $45 \%$. Anaerobic treatment with the UASB reactor was very effective for removing the biodegradable organic matter, but not for removing phosphate and ammonia. The effluent concentration of $\mathrm{P}$ and $\mathrm{N}$ was increased from 38.5 to $79 \mathrm{mg} / \mathrm{L} \mathrm{P}_{\text {tot }}$ and from 190 to $638 \mathrm{mg} / \mathrm{L} \mathrm{N} \mathrm{N}_{\text {tot }}$ during the experiments.

\section{CONCLUSION}

The investigation of the cheese industry wastewater treatment has demonstrated that the process of anaerobic degradation can be successfully for COD removal. The UASB reactor proved to be a very reliable unit throughout the year. No problems occurred with restarting the UASB reactor when there had been a standstill over a period of some weeks. The optimum parameters for treating cheese whey wastewater, such us

organic load before $7.5 \mathrm{~kg} \mathrm{COD} / \mathrm{m}^{3}$-day

HRT 10 days

treatment efficiency $\quad 70-98 \% \mathrm{COD}$

temperature $\quad 35-37^{\circ} \mathrm{C}$

may be recommended. The treated cheese whey may be directed to the municipal treatment plant.

\section{ACKNOWLEDGEMENT}

The authors express their appreciation to the Estonian Science Founda-tion for their financial support (GRANT 3427). 


\section{REFERENCES}

Gavala H.N., Kopsinis H., Skidas I.V, Stamatelatou K., and Lyberatos G. (1997). Treatment of dairy wastewater using a UASBR. In : Proc. 8 th. International Conf. on Anaerobic Digestion., vol 3, 4p. Hanging Y. and Guowei G. (1996) Biomethanation of brewery wastewater using an anaerobic upflow blanket filter. Cleaner Prod., 4, (3-4), pp. 219-223.

Kalyuzhnyi S.V., Danilovitsh D.A., and Kozhevnikov A.H. ( 1991 ). Anaerobic Biological Wastewaters Treatment. M. Reports of Science and Engineering, Series Biotechnology, 29, pp 1-155. (In Russian).

Kalyuzhnyi S., Martinez E.P., and Martinez J.R. ( 1997 ). Anaerobic treatment of raw cheese whey wastewater in laboratory and pilot UASB reactoris. In: Porch. $8^{\text {th }}$. International Conf. on Anaerobic Digestion.. Vol 3, 4p.

Lettinga G.. Field J., Lier J., Zeeman G., and Hulshoff L. W. (1997). Advanced anaerobic wastewater treatment in the near future. Wat.Sci: Tech., 35 (10), pp.5-12. DOI: https://doi.org/10.1016/S0273-1223(97)00222-9

Malina I.F. and Pohland F.G.(1992). Water Quality Management Library. Volume 7. Design of Anaerobic Processes for the Treatment of Industrial and Municipal Wastes, USA. 214p.

Seyfried C.F. and Austermann-Haun U. (1997). Full-scale experiences with the anaerobic pretreatment of industrial wastewater in Germany . In: Porch. $8^{\text {th }}$. International Conf. on Anaerobic Digestion.. Vol 1, 8p.

Sutton P.M. ( 1990 ) Anaerobic Treatment of High Strength Wastes: System Configurations and Selection, Presented at Anaerobic Treatment of High Strength Wastes, University of Wisconsin Milwaukel. Milwaukee, Wisconsin.

Yan J.Q.. Lo K.V., and Pinder K.L. (1993). Instability caused by high strength of cheese whey in a UASB reactor. Biotechnol. Bioeng., 41, pp. 700 -706. DOI: https://doi.org/10.1002/bit.260410704 